\title{
Salidroside prevents hydroperoxide-induced oxidative stress and apoptosis in retinal pigment epithelium cells
}

\author{
YAN YIN $^{1 *}$, DEJIE LIU ${ }^{2 *}$ and DONGHUA TIAN ${ }^{1}$ \\ ${ }^{1}$ Department of Ophthalmology, Jining No. 1 People's Hospital, Jining, Shandong 272011; \\ ${ }^{2}$ Department of Ophthalmology, Yantai Yeda Hospital, Yantai, Shandong 264006, P.R. China
}

Received December 3, 2017; Accepted June 29, 2018

DOI: $10.3892 /$ etm.2018.6494

\begin{abstract}
Salidroside (SAL) is the major pharmacologically active constituent of Rhodiola rosea, which possesses a wide range of pharmacological functions, including anti-aging, anti-inflammatory, antioxidant, anticancer and neuroprotective activities. However, the effects and mechanisms of SAL on oxidative stress in retinal pigment epithelial (RPE) cells exposed to hydrogen peroxide $\left(\mathrm{H}_{2} \mathrm{O}_{2}\right)$ remain unclear. The present study investigated the protective effects of SAL and the underlying mechanisms against $\mathrm{H}_{2} \mathrm{O}_{2}$-induced oxidative stress in human RPE cells. ARPE-19 cells were treated with various doses of SAL for $24 \mathrm{~h}$ and then exposed to $200 \mu \mathrm{M} \mathrm{H}_{2} \mathrm{O}_{2}$ for $24 \mathrm{~h}$. Cell viability was analyzed by a MTT assay, and the intracellular levels of reactive oxygen species were measured using CellROX orange reagent. Cell apoptosis was analyzed by annexin V/propidium iodide double staining, followed by flow cytometry. The levels of B-cell lymphoma 2 (Bcl-2), Bcl-2-associated $\mathrm{X}$ protein, phospho (p)-protein kinase $\mathrm{B}$ (Akt), Akt, p-glycogen synthase kinase (GSK)-3 $\beta$ and GSK-3 $\beta$ were evaluated using western blotting. The results demonstrated that SAL markedly attenuated $\mathrm{H}_{2} \mathrm{O}_{2}$-induced loss of cell viability. SAL also ameliorated $\mathrm{H}_{2} \mathrm{O}_{2}$-induced oxidative stress and cell apoptosis in RPE cells. In addition, pretreatment with SAL significantly increased the phosphorylation levels of Akt and GSK-3 $\beta$ in $\mathrm{H}_{2} \mathrm{O}_{2}$-treated ARPE-19 cells. In conclusion, the present study demonstrated that SAL protected RPE cells against $\mathrm{H}_{2} \mathrm{O}_{2}$-induced cell injury through the activation of the Akt/GSK-3 $\beta$ signaling pathway. This suggests that SAL may be a potential therapeutic strategy for the treatment of age-related macular degeneration.
\end{abstract}

Correspondence to: Dr Donghua Tian, Department of Ophthalmology, Jining No. 1 People's Hospital, 6 Health Road, Jining, Shandong 272011, P.R. China

E-mail: tiandong_hua@126.com

*Contributed equally

Key words: salidroside, age-related macular degeneration, oxidative stress, apoptosis

\section{Introduction}

Age-related macular degeneration (AMD) is the leading cause of visual loss after the age of 60 years (1). Although the exact pathogenic mechanism of AMD is still unknown, numerous reports provide evidence that oxidative stress plays an important role in the pathophysiology of AMD. Retinal pigment epithelial (RPE) is a monolayer of differentiated cells located between the neural retina and Bruch's membrane, performing essential functions for the maintenance of the normal visual process (2). During AMD, excessive oxidative stress occurs, resulting in the accumulation of reactive oxygen species (ROS), causing damage to RPE cells (3-5). Excessive ROS causes an oxidative cascade, mediated in part by ROS-induced activation of NF-kB, STAT, and AP-1 transcription factors leading to oxidative injury to macromolecules in RPE cells, which ultimately contributes to the pathogenesis of AMD (6). Thus, inhibiting $\mathrm{H}_{2} \mathrm{O}_{2}$-induced RPE cell injury may be a therapeutic approach for the treatment of AMD.

Salidroside (SAL) is the major phenylpropanoid glycoside and pharmacological active constituent of Rhodiola rosea. Previous studies have been shown that SAL possesses a wide range of pharmacological functions, including anti-aging, anti-inflammatory, antioxidant, anti-cancer and neuroprotective activities (7-11). For example, Zhang et al (12) reported that pretreatment with SAL dose-dependently upregulated the production of antioxidant enzymes and inhibited the elevation of intracellular ROS level in Abeta-induced human neuroblastoma cells. However, the effects and mechanisms of SAL on oxidative stress in RPE cells exposed to hydrogen peroxide $\left(\mathrm{H}_{2} \mathrm{O}_{2}\right)$ remain unclear. Therefore, the purpose of this study was to investigate its protective effects and the underlying mechanisms against $\mathrm{H}_{2} \mathrm{O}_{2}$-induced oxidative stress in human RPE cells. The results indicated that SAL protects RPE cells against $\mathrm{H}_{2} \mathrm{O}_{2}$-induced cell injury through the activation of Akt/GSK-3 $\beta$ signaling pathway.

\section{Materials and methods}

Cell culture. The human RPE cell line ARPE-19 was obtained from the American Type Culture Collection (ATCC; Manassas, VA, USA) and maintained in a 1:1 mixture of Dulbecco's modified Eagle's medium (DMEM) and nutrient mixture F-12 (Life Technologies, Carlsbad, CA, USA) supplemented 
with $10 \%$ fetal bovine serum (FBS), $100 \mathrm{U} / \mathrm{ml}$ penicillin, $100 \mu \mathrm{g} / \mathrm{ml}$ streptomycin, and $2 \mathrm{mM}$ l-glutamine (Lonza, Basel, Switzerland). The cells were cultured in a humidified incubator at $37^{\circ} \mathrm{C}$ and $5 \% \mathrm{CO}_{2}$.

Cell viability assay. Cell viability was evaluated using the MTT assay. In brief, ARPE-19 cells at a density of $1 \times 10^{4}$ cells/well were incubated with or without SAL $(12.5-100 \mu \mathrm{g} / \mathrm{ml})$ for $24 \mathrm{~h}$ and then treated with $200 \mu \mathrm{M} \mathrm{H}_{2} \mathrm{O}_{2}$ for $6 \mathrm{~h}$. Next, $50 \mu \mathrm{l}$ of MTT solution $(5 \mathrm{mg} / \mathrm{ml}$; Sigma-Aldrich; Merck KGaA, Darmstadt, Germany) was added into each well, and the plate was incubated for $4 \mathrm{~h}$ at $37^{\circ} \mathrm{C}$. Then the supernatant was removed and $100 \mu \mathrm{l}$ DMSO (Sigma-Aldrich; Merck KGaA) was added to dissolve formazan. The absorbance was read at $490 \mathrm{~nm}$ using an enzyme linked immunosorbent assay plate reader (Olympus, Tokyo, Japan). The experiment was performed in triplicate.

Cell cytotoxicity assay. The cytotoxicity of treated ARPE-19 cells was evaluated via determining the activity of lactate dehydrogenase (LDH) enzyme released into medium with the CytoTox96 ${ }^{\circledR}$ Non-Radioactive Cytotoxicity Assay (Promega, Fitchburg, WI, USA) according to the manufacturer's instructions. The experiment was performed in triplicate.

Cell apoptosis assay. After treatment, ARPE-19 cells were harvested by trypsinization. Then, the cells were centrifuged, washed twice with PBS and resuspended in 1X Binding Buffer. After adding $5 \mu \mathrm{l}$ of Annexin V-FITC solution and $5 \mu \mathrm{l}$ of PI solution according to the instructions of Annexin V-FITC apoptosis detection kit (Beyotime Institute of Biotechnology, Nantong, China), cells were incubated in the dark for $30 \mathrm{~min}$ at room temperature. The experiment was performed in triplicate.

Detection of ROS. After treatment, ARPE-19 cells were loaded with $5 \mathrm{mM}$ CellROX orange reagent for $30 \mathrm{~min}$ at $37^{\circ} \mathrm{C}$. Then, the fluorescence intensity of CellRox Green in each well was measured using SpectraMax 5 (Molecular Devices, Downington, PA, USA) following manufacturer's instructions. The experiment was performed in triplicate.

Reverse transcription-quantitative polymerase chain reaction $(R T-q P C R)$. Total RNA was extracted from ARPE-19 cells using TRIzol reagent (Invitrogen; Thermo Fisher Scientific, Inc., Waltham, MA, USA). First-strand cDNA was synthesized with the Prime Script RT reagent kit (Takara Bio Inc., Otsu, Japan). PCR amplification was carried out by ABI PRISM 7900 thermocycler using SYBR Premix Taq (Applied Biosystems, Foster City, CA, USA). The primers used were as follows: for Bcl-2 forward, 5'-CAAAGGTGGATCAGATTC AAG-3' and reverse, 5'-GGTGAGCATTATCACCCAGAA-3'; for Bax forward, 5'-TGGCAGCAGTGACAGCAGCG-3' and reverse, 5'-TACGGAGGTGGAGTGGGTGT-3'; and for GAPDH forward, 5'-TGACTTCAACAGCGACACCCA-3' and 5'-CAC CCTGTTGCTGTAGCCAAA-3'. The comparative threshold cycle method $(\Delta \Delta \mathrm{Cq})$ was used to determine the levels of gene expression (13). The experiment was performed in triplicate.

Western blot analysis. ARPE-19 cells were homogenized and lysed with RIPA lysis buffer (Beyotime Institute of
Biotechnology). Then, protein concentrations were measured with a BCA protein assay kit (Pierce, Rockford, IL, USA). The proteins ( $30 \mu \mathrm{g} /$ lane) were subjected to $10 \%$ sodium dodecyl sulfate polyacrylamide gel (SDS-PAGE) and transferred to Immobilon P EMD Millipore (Billerica, MA, USA). After blocking with $5 \%$ non-fat milk in PBS with Tween-20 buffer at room temperature for $1 \mathrm{~h}$, the blots were incubated for $60 \mathrm{~min}$ at room temperature with primary antibody against the following: Bcl-2, Bax, Akt, phosphorylated Akt, GSK-3 $\beta$, phosphorylated GSK-3 $\beta$ or GAPDH (diluted 1:1,000 in TBST; Santa Cruz Biotechnology, Santa Cruz, CA, USA). Subsequently, the membranes were incubated with horseradish-peroxidase-conjugated secondary antibody (1:1,000; Santa Cruz Biotechnology) for $1 \mathrm{~h}$ at room temperature. Detection was performed using the ECL western blotting detection system (Thermo Fisher Scientific, Inc.). Each band density was quantified using Quantity One software (Bio-Rad, Richmond, CA, USA) and normalized to GAPDH. The experiment was performed in triplicate.

Statistical analysis. Statistical analysis was made using Prism (GraphPad Software, San Diego, CA, USA). Data are expressed as mean \pm standard deviation. Significance was determined by one-way analysis of variance followed by Tukey's post-hoc test. $\mathrm{P}<0.05$ was considered to indicate a statistically significant difference.

\section{Results}

Pretreatment with SAL markedly attenuated $\mathrm{H}_{2} \mathrm{O}_{2}$-induced loss of cell viability. To study the effect of SAL on RPE cell viability, ARPE-19 cells were treated with increasing concentrations of SAL $(12.5,25,50$ or $100 \mu \mathrm{g} / \mathrm{ml})$. As shown in Fig. 1A, $100 \mu \mathrm{g} / \mathrm{ml}$ of SAL significantly decreased cell viability. Cell viability of ARPE-19 cells was not significantly impaired by concentrations of SAL $<100 \mu \mathrm{g} / \mathrm{ml}$. Then, we detected the effect of various concentrations of $\mathrm{H}_{2} \mathrm{O}_{2}$ on RPE cell viability. The results showed that $200 \mu \mathrm{M} \mathrm{H}_{2} \mathrm{O}_{2}$ could significantly reduce cell viability. Since the effects of 200 and $300 \mu \mathrm{M} \mathrm{H}_{2} \mathrm{O}_{2}$ were not significantly different, $200 \mu \mathrm{M} \mathrm{H}_{2} \mathrm{O}_{2}$ was chosen for subsequent experiments (Fig. 1B). In addition, the effect of SAL on cell viability in $\mathrm{H}_{2} \mathrm{O}_{2}$-treated ARPE-19 cells was evaluated. The results of MTT assay demonstrated that the viability of RPE cells treated with $200 \mu \mathrm{M} \mathrm{H}_{2} \mathrm{O}_{2}$ significantly decreased compared with the untreated group. However, pretreatment with SAL obviously increased the viability of RPE cells in a dose-dependent manner (Fig. 1C). We further analyzed whether SAL pretreatment could influence $\mathrm{H}_{2} \mathrm{O}_{2}$-induced cellular cytotoxicity. As shown in Fig. 1D, the exposure to $200 \mu \mathrm{M} \mathrm{H}_{2} \mathrm{O}_{2}$ greatly increased LDH release. However, the LDH release gradually down to 274.3, 223.7, and $164.1 \%$ with increasing concentrations of SAL, respectively.

Pretreatment with $\mathrm{SAL}$ ameliorated $\mathrm{H}_{2} \mathrm{O}_{2}$-induced oxidative stress in RPE cells. It is known that oxidative stress plays a pivotal role in AMD pathogenesis. Thus, we examined the effect of SAL in on oxidative stress in $\mathrm{H}_{2} \mathrm{O}_{2}$-treated ARPE-19 cells. As shown in Fig. 2, as compared with the control group, the level of intracellular ROS was significantly increased in 

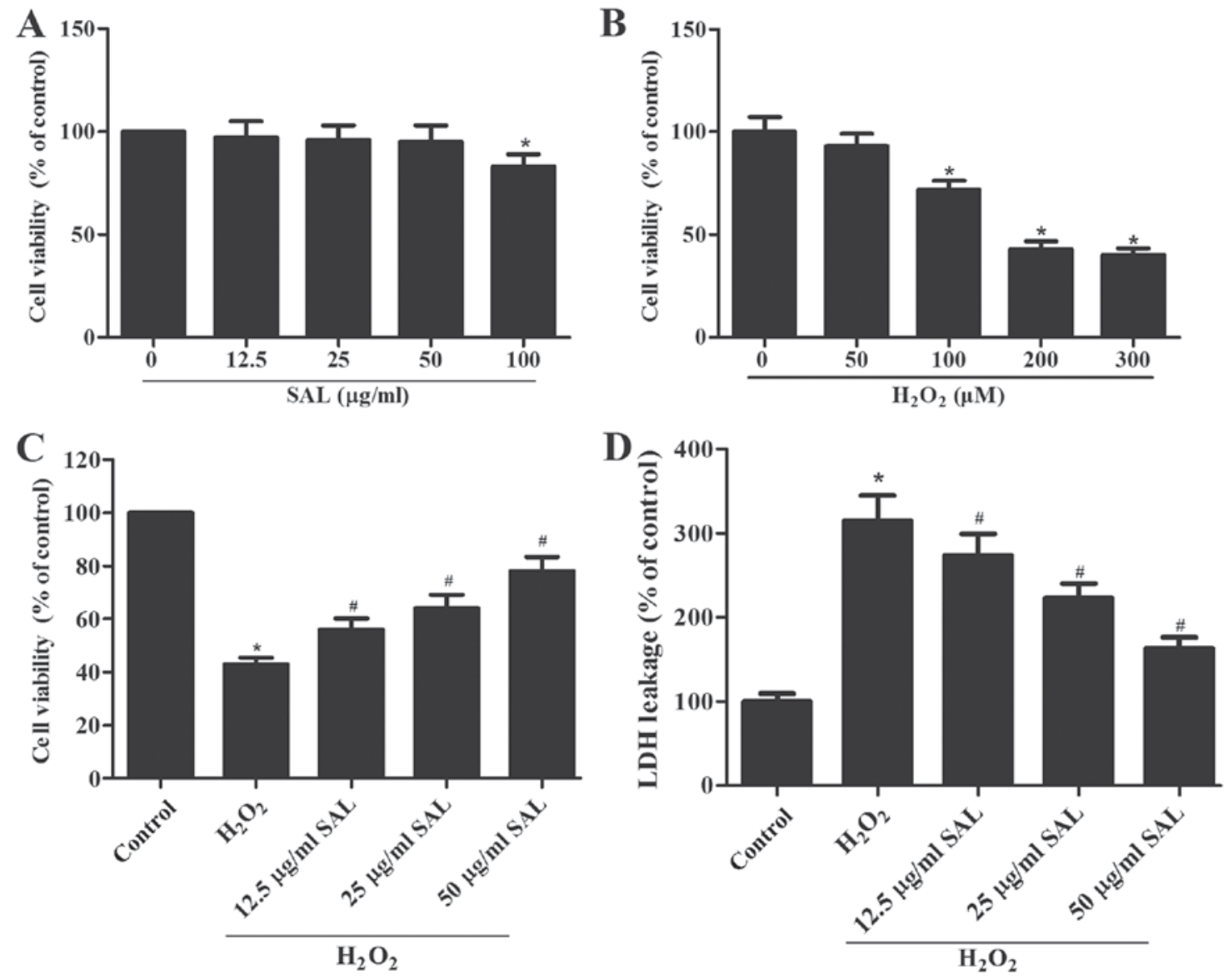

Figure 1. Pretreatment with SAL markedly attenuates $\mathrm{H}_{2} \mathrm{O}_{2}$-induced loss of cell viability. (A) ARPE-19 cells were treated with various doses of SAL $(0,12.5$, $25,50$ and $100 \mu \mathrm{g} / \mathrm{ml})$ for $24 \mathrm{~h}$ and the cell viability was analyzed by an MTT assay. (B) ARPE-19 cells were incubated with various concentrations of $\mathrm{H}_{2} \mathrm{O}_{2}(0$, 50, 100, 200 and $300 \mu \mathrm{M}$ ) for $24 \mathrm{~h}$ and cell viability was detected by an MTT assay. (C) ARPE-19 cells were incubated with various doses of SAL ( $0,12.5,25$ and $50 \mu \mathrm{g} / \mathrm{ml}$ ) for $24 \mathrm{~h}$ and then exposed to $200 \mu \mathrm{M} \mathrm{H}_{2} \mathrm{O}_{2}$ for $24 \mathrm{~h}$. Cell viability was analyzed by an MTT assay. (D) Cell cytotoxicity was analyzed by an LDH assay. Data are expressed as the mean \pm standard deviation from a minimum of three independent experiments. ${ }^{*} \mathrm{P}<0.05$ vs. the control group. ${ }^{\# P}<0.05$ vs. the $\mathrm{H}_{2} \mathrm{O}_{2}$ group. SAL, salidroside; $\mathrm{H}_{2} \mathrm{O}_{2}$, hydrogen peroxide.

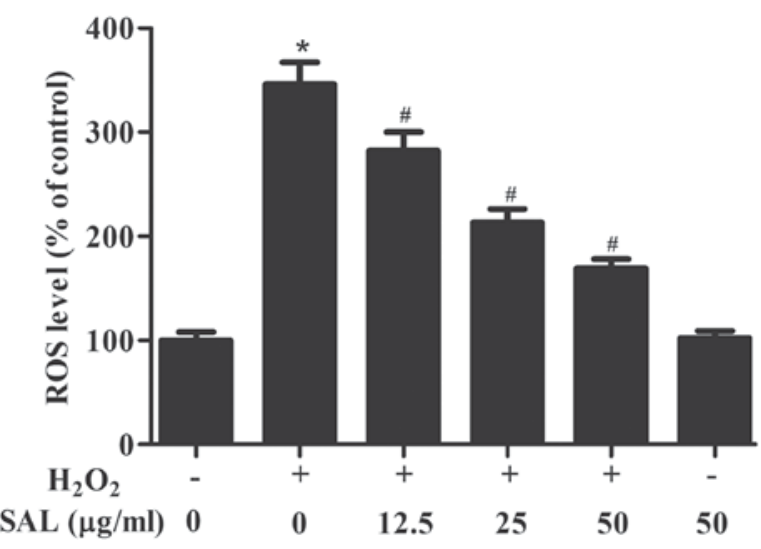

Figure 2. Pretreatment with SAL ameliorates $\mathrm{H}_{2} \mathrm{O}_{2}$-induced oxidative stress in retinal pigment epithelial cells. ARPE-19 cells were incubated with various doses of SAL $(0,12.5,25$ and $50 \mu \mathrm{g} / \mathrm{ml})$ for $24 \mathrm{~h}$ and then exposed to $200 \mu \mathrm{M}$ $\mathrm{H}_{2} \mathrm{O}_{2}$ for $24 \mathrm{~h}$ or only treated with $50 \mu \mathrm{g} / \mathrm{ml} \mathrm{SAL}$ for $24 \mathrm{~h}$. The intracellular levels of ROS were measured using CellROX orange reagent. Data are expressed as the mean \pm standard deviation from a minimum of three independent experiments. ${ }^{*} \mathrm{P}<0.05$ vs. the control group. ${ }^{\sharp} \mathrm{P}<0.05$ vs. the $\mathrm{H}_{2} \mathrm{O}_{2}$ group. SAL, salidroside; $\mathrm{H}_{2} \mathrm{O}_{2}$, hydrogen peroxide; ROS, reactive oxygen species

$\mathrm{H}_{2} \mathrm{O}_{2}$-treated ARPE-19 cells. However, pretreatment with SAL markedly reduced $\mathrm{H}_{2} \mathrm{O}_{2}$-induced ROS level in ARPE-19 cells.
In addition, SAL alone treatment did not affect ROS level in ARPE-19 cells.

Pretreatment with SAL inhibited $\mathrm{H}_{2} \mathrm{O}_{2}$-induced cell apoptosis in RPE cells. $\mathrm{H}_{2} \mathrm{O}_{2}$ has been shown to induce apoptosis in RPE cells. Thus, we examined the effect of SAL on ARPE-19 cell apoptosis induced by $\mathrm{H}_{2} \mathrm{O}_{2}$. As shown in Fig. 3, the exposure to $200 \mu \mathrm{M} \mathrm{H}_{2} \mathrm{O}_{2}$ for $24 \mathrm{~h}$ would lead to a significant higher rate of apoptosis, compared with the control cells. Pretreatment with SAL dramatically reversed $\mathrm{H}_{2} \mathrm{O}_{2}$-induced apoptosis. In addition, we observed that pretreatment with SAL significantly upregulated the expression of Bcl-2 and downregulated the expression of Bax, as compared with the $\mathrm{H}_{2} \mathrm{O}_{2}$ group (Fig. 3).

Pretreatment with SAL activated Akt/GSK-3 $\beta$ signaling pathway in RPE cells. It has been reported that the activation of Akt/GSK-3 $\beta$ signaling pathway plays an important role in the progression of AMD (14), we examined the effects of SAL on Akt/GSK-3 $\beta$ signaling pathway in $\mathrm{H}_{2} \mathrm{O}_{2}$-treated ARPE-19 cells. The results of western blot analysis indicated that the phosphorylation levels of Akt and GSK-3 $\beta$ were not significantly activated in $\mathrm{H}_{2} \mathrm{O}_{2}$-stimulated ARPE-19 cells. Pretreatment with SAL significantly increased the phosphorylation levels of Akt and GSK-3 $\beta$ in $\mathrm{H}_{2} \mathrm{O}_{2}$-treated ARPE-19 
A

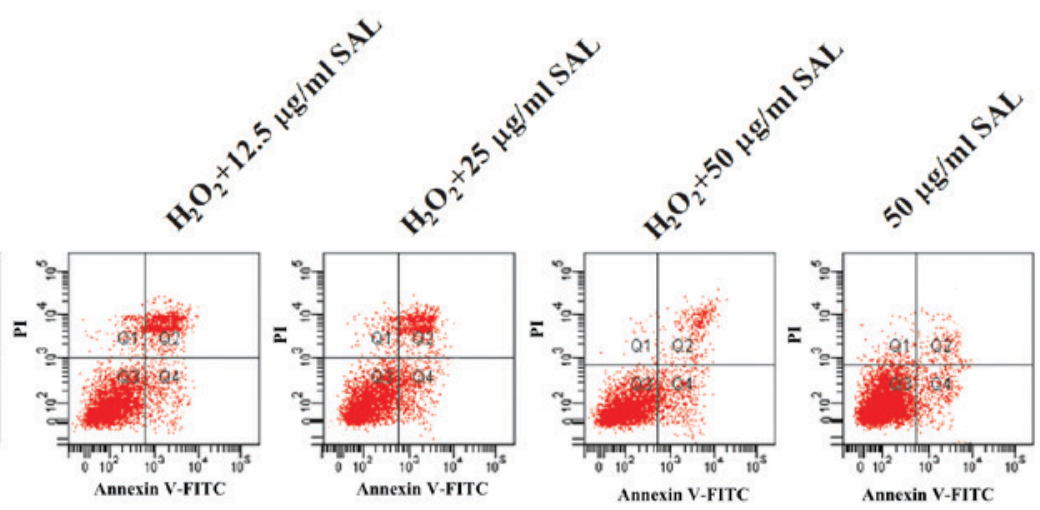

B

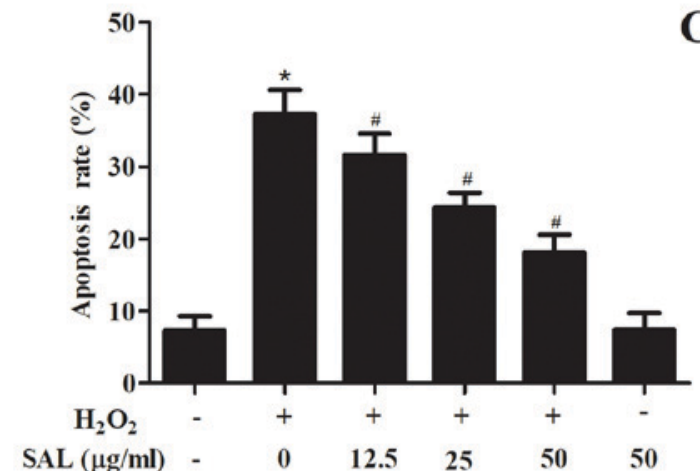

C

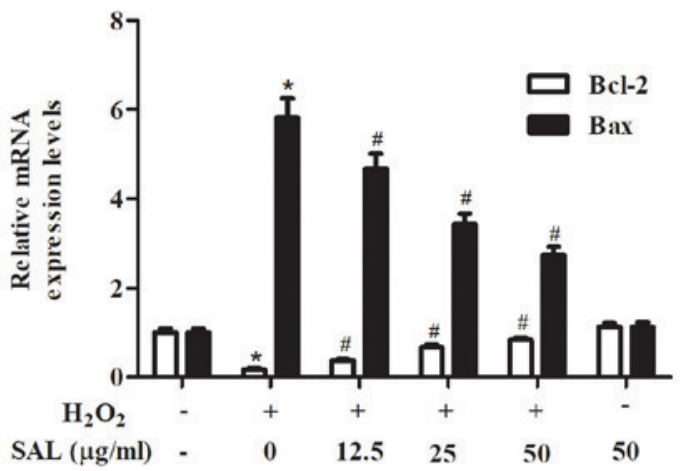

D

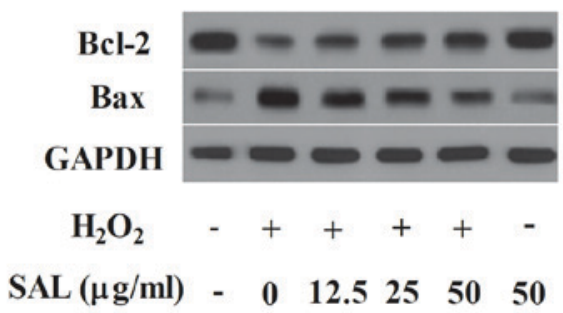

$\mathbf{E}$

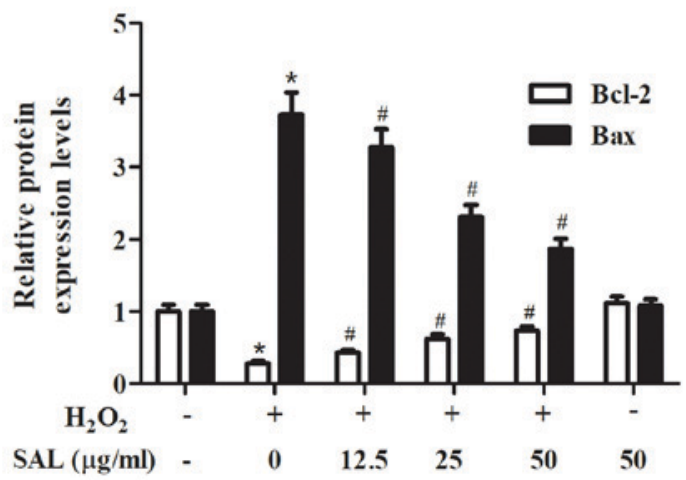

Figure 3. Pretreatment with SAL inhibits $\mathrm{H}_{2} \mathrm{O}_{2}$-induced cell apoptosis in retinal pigment epithelial cells. ARPE-19 cells were incubated with various doses of SAL $(0,12.5,25$ and $50 \mu \mathrm{g} / \mathrm{ml})$ for $24 \mathrm{~h}$ and then exposed to $200 \mu \mathrm{M} \mathrm{H}_{2} \mathrm{O}_{2}$ for $24 \mathrm{~h}$ or only treated with $50 \mu \mathrm{g} / \mathrm{ml} \mathrm{SAL}$ for $24 \mathrm{~h}$. (A) Cell apoptosis was analyzed by Annexin V/PI double staining, followed by flow cytometry. (B) Quantification analysis of cell apoptosis. (C) The mRNA levels of Bcl-2 and Bax were evaluated using reverse transcription-quantitative polymerase chain reaction. (D) Protein expression of Bcl-2 and Bax were evaluated by western blot analysis. (E) Quantification analysis of Bcl-2 and Bax was performed using Quantity One software. Data are expressed as the mean \pm standard deviation from a minimum of three independent experiments. " $\mathrm{P}<0.05$ vs. the control group. ${ }^{~} \mathrm{P}<0.05$ vs. the $\mathrm{H}_{2} \mathrm{O}_{2}$ group. $\mathrm{SAL}$, salidroside; PI, propidium iodide; $\mathrm{Bcl}-2$, $\mathrm{B}$ cell lymphoma-2; $\mathrm{H}_{2} \mathrm{O}_{2}$, hydrogen peroxide.
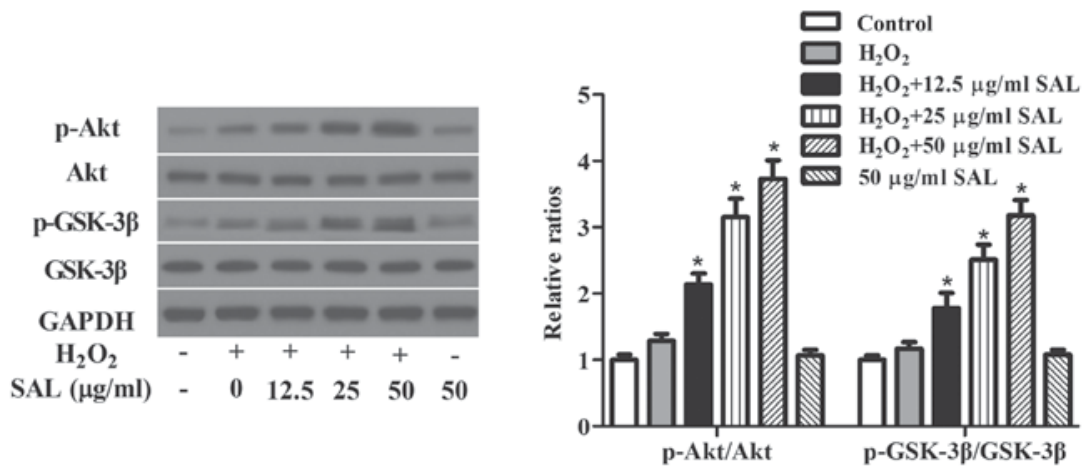

Figure 4. Pretreatment with SAL activates the Akt/GSK-3 $\beta$ signaling pathway in retinal pigment epithelial cells. ARPE-19 cells were incubated with various doses of SAL $(0,12.5,25$ and $50 \mu \mathrm{g} / \mathrm{ml})$ for $24 \mathrm{~h}$ and then exposed to $200 \mu \mathrm{M} \mathrm{H}_{2} \mathrm{O}_{2}$ for $24 \mathrm{~h}$ or only treated with $50 \mu \mathrm{g} / \mathrm{ml} \mathrm{SAL}$ for $24 \mathrm{~h}$. The protein expression of p-Akt, Akt, p-GSK-3 $\beta$ and GSK-3 $\beta$ were evaluated by western blot anlaysis. Data are expressed as the mean \pm standard deviation from a minimum of three independent experiments. "P<0.05 vs. the control group. p-, phosphorylated; Akt, protein kinase B; GSK, glycogen synthase kinase; SAL, salidroside; $\mathrm{H}_{2} \mathrm{O}_{2}$, hydrogen peroxide. 
cells. Additionally, SAL alone treatment did not affect the activation of Akt/GSK-3 $\beta$ pathway (Fig. 4).

\section{Discussion}

To our knowledge, we have shown for the first time that SAL markedly attenuated $\mathrm{H}_{2} \mathrm{O}_{2}$-induced loss of cell viability. SAL also ameliorated $\mathrm{H}_{2} \mathrm{O}_{2}$-induced oxidative stress and cell apoptosis in RPE cells. Furthermore, pretreatment with SAL significantly increased the phosphorylation levels of Akt and GSK-3 $\beta$ in $\mathrm{H}_{2} \mathrm{O}_{2}$-treated ARPE-19 cells.

Previous studies reported that $\mathrm{H}_{2} \mathrm{O}_{2}$ can decrease RPE cell viability, which induce AMD progression (15-17). In line with these previous studies, our present study confirmed that $\mathrm{H}_{2} \mathrm{O}_{2}$ significantly decreased cell viability, as evidenced by the MTT assay. Meanwhile, we observed that pretreatment with SAL obviously increased the viability and reduced $\mathrm{LDH}$ release in $\mathrm{H}_{2} \mathrm{O}_{2}$-induced ARPE-19 cells in a dose dependent manner. These observations suggest that SAL protected human RPE cells from $\mathrm{H}_{2} \mathrm{O}_{2}$-induced oxidative stress through increasing the viability and reducing $\mathrm{LDH}$ release.

Numerous studies have demonstrated that oxidative stress is a major stimulus in the pathogenesis of AMD (18-20). SAL is a strong antioxidative supplement in Chinese traditional medicine. It was confirmed that SAL effectively attenuated the production of ROS in human umbilical vein endothelial cells (HUVECs) under conditions of oxidative injury induced by $\mathrm{H}_{2} \mathrm{O}_{2}$ (21). Another study reported that SAL effectively inhibited oxidative stress in cardiac $\mathrm{H} 9 \mathrm{c} 2$ cells induced by $\mathrm{H}_{2} \mathrm{O}_{2}$ insult (22). In accordance with previous studies, in the present study, we observed that pretreatment with SAL markedly reduced $\mathrm{H}_{2} \mathrm{O}_{2}$-induced ROS level in ARPE-19 cells. These data suggest that SAL effectively protected human RPE cells from $\mathrm{H}_{2} \mathrm{O}_{2}$-induced oxidative stress via antioxidant effect.

Previous studies showed that oxidative stress induces mitochondrial dysfunction and promotes apoptosis correlating with increased Bax expression and decreased Bcl-2 expression in human RPE cells $(23,24)$. Bcl-2 is a key anti-apoptotic member of the Bcl-2 family that regulates the intrinsic apoptosis pathway. In addition, it was reported that SAL increased the ratio of $\mathrm{Bcl} 2 / \mathrm{Bax}$ in $\mathrm{H}_{2} \mathrm{O}_{2}$-induced retinal endothelial cells (25). Similarly, in the present study, we observed that pretreatment with SAL upregulated the expression of Bcl-2 and downregulated the expression of $\mathrm{Bax}$ in $\mathrm{H}_{2} \mathrm{O}_{2}$-treated ARPE-19 cells. These data suggest that SAL effectively protected human RPE cells from $\mathrm{H}_{2} \mathrm{O}_{2}$-induced oxidative stress via anti-apoptotic effect.

The Akt/GSK-3 $\beta$ signaling pathway plays a crucial role in a variety of cellular processes such as cell proliferation and apoptosis (26-28). Akt activation enhances RPE cell survival and thus may protect RPE cells from oxidant-induced cell death in the pathogenesis of AMD (29). Previous studies demonstrated that adding $\mathrm{H}_{2} \mathrm{O}_{2}$ to RPE cells caused Akt activation $(29,30)$. In the present study, we observed that Akt phosphorylation was moderately enhanced in the stimulation of $\mathrm{H}_{2} \mathrm{O}_{2}$. In addition, pretreatment with SAL significantly increased the phosphorylation levels of Akt and GSK-3 $\beta$ in $\mathrm{H}_{2} \mathrm{O}_{2}$-treated ARPE-19 cells. These results suggest that SAL protected RPE cells against $\mathrm{H}_{2} \mathrm{O}_{2}$-induced cell injury through the activation of Akt/ GSK-3 $\beta$ signaling pathway.
In conclusion, this study demonstrated that SAL could stimulate the recovery of RPE cells under oxidative stress through the activation of Akt/GSK-3 $\beta$ signaling. These data suggest that SAL may be a potential therapeutic strategy for the prevention and therapy of AMD.

\section{Acknowledgements}

Not applicable.

\section{Funding}

No funding was received.

\section{Availability of data and materials}

All data generated or analyzed during this study are included in this published article.

\section{Authors' contributions}

DT conceived and designed the experiments. YY and DL performed the experiments. DL analyzed the data. All authors have read and approved the final manuscript.

\section{Ethics approval and consent to participate}

Not applicable.

\section{Patient consent for publication}

Not applicable.

\section{Competing interests}

The authors declare that they have no competing interests.

\section{References}

1. Friedman DS, O'Colmain BJ, Muñoz B, Tomany SC, Mccarty C, de Jong PT, Nemesure B, Nemesure B, Mitchell P and Kempen J; Eye Diseases Prevalence Research Group: Prevalence of age-related macular degeneration in the United States. Arch Ophthalmol 122: 564-572, 2004.

2. Strauss O: The retinal pigment epithelium in visual function. Physiol Rev 85: 845-881, 2005.

3. Dong A, Xie B, Shen J, Yoshida T, Yokoi K, Hackett SF and Campochiaro PA: Oxidative stress promotes ocular neovascularization. J Cell Physiol 219: 544-552, 2009.

4. Lu L, Hackett SF, Mincey A, Lai H and Campochiaro PA: Effects of different types of oxidative stress in RPE cells. J Cell Physiol 206: 119-125, 2006.

5. Glotin AL, Calipel A, Brossas JY, Faussat AM, Tréton J and Mascarelli F: Sustained versus transient ERK1/2 signaling underlies the anti- and proapoptotic effects of oxidative stress in human RPE cells. Invest Ophthalmol Vis Sci 47: 4614-4623, 2006.

6. Beatty S, Koh H, Phil M, Henson D and Boulton M: The role of oxidative stress in the pathogenesis of age-related macular degeneration. Surv Ophthalmol 45: 115-134, 2000.

7. Sun L, Isaak CK, Zhou Y, Petkau JC, O K, Liu Y and Siow YL: Salidroside and tyrosol from Rhodiola protect H9c2 cells from ischemia/reperfusion-induced apoptosis. Life Sci 91: 151-158, 2012.

8. Li D, Fu Y, Zhang W, Su G, Liu B, Guo M, Li F, Liang D, Liu Z, Zhang $\mathrm{X}$, et al: Salidroside attenuates inflammatory responses by suppressing nuclear factor- $\kappa \mathrm{B}$ and mitogen activated protein kinases activation in lipopolysaccharide-induced mastitis in mice. Inflamm Res 62: 9-15, 2013. 
9. Mao GX, Wang Y, Qiu Q, Deng HB, Yuan LG, Li RG, Song DQ, Li YY, Li DD and Wang Z: Salidroside protects human fibroblast cells from premature senescence induced by $\mathrm{H}(2) \mathrm{O}(2)$ partly through modulating oxidative status. Mech Ageing Dev 131: 723-731, 2010.

10. Hu X, Zhang X, Qiu S, Yu D and Lin S: Salidroside induces cell-cycle arrest and apoptosis in human breast cancer cells. Biochem Bioph Res Commun 398: 62-67, 2010.

11. Shi TY, Feng SF, Xing JH, Wu YM, Li XQ, Zhang N, Tian Z, Liu SB and Zhao MG: Neuroprotective effects of Salidroside and its analogue tyrosol galactoside against focal cerebral ischemia in vivo and $\mathrm{H} 2 \mathrm{O} 2$-induced neurotoxicity in vitro. Neurotox Res 21: 358-367, 2012.

12. Zhang L, Yu H, Zhao X, Lin X, Tan C, Cao G and Wang Z: Neuroprotective effects of salidroside against beta-amyloid-induced oxidative stress in SH-SY5Y human neuroblastoma cells. Neurochem Int 57: 547-555, 2010.

13. Baek SM, Yu SY, Son Y and Hong HS: Substance P promotes the recovery of oxidative stress-damaged retinal pigmented epithelial cells by modulating Akt/GSK-3 $\beta$ signaling. Mol Vis 22 : 1015-1023, 2016.

14. Cao X, Liu M, Tuo J, Shen D and Chan CC: The effects of quercetin in cultured human RPE cells under oxidative stress and in $\mathrm{Ccl} 2 / \mathrm{Cx} 3 \mathrm{cr} 1$ double deficient mice. Exp Eye Res 91: 15-25, 2010

15. Cia D, Vergnaud-Gauduchon J, Jacquemot $\mathrm{N}$ and Doly $\mathrm{M}$ Epigallocatechin gallate (EGCG) prevents $\mathrm{H} 2 \mathrm{O} 2$-induced oxidative stress in primary rat retinal pigment epithelial cells. Curr Eye Res 39: 944-952, 2014

16. Koskela A, Reinisalo M, Hyttinen JM, Kaarniranta K and Karjalainen RO: Pinosylvin-mediated protection against oxidative stress in human retinal pigment epithelial cells. Mol Vis 20: 760-769, 2014

17. Liang FQ and Godley BF: Oxidative stress-induced mitochondrial DNA damage in human retinal pigment epithelial cells: A possible mechanism for RPE aging and age-related macular degeneration. Exp Eye Res 76: 397-403, 2003.

18. Beatty S, Koh H, Phil M, Henson D and Boulton M: The role of oxidative stress in the pathogenesis of age-related macular degeneration. Surv Ophthalmol 45: 115-134, 2000.

19. Klein R, Myers CE, Cruickshanks KJ, Gangnon RE, Danforth LG, Sivakumaran TA, Iyengar SK, Tsai MY and Klein BE: Markers of inflammation, oxidative stress, and endothelial dysfunction and the 20-year cumulative incidence of early age-related macular degeneration: The beaver dam eye study. JAMA Ophthalmol 132. 446-455, 2014.

20. Xu MC, Shi HM, Wang H and Gao XF: Salidroside protects against hydrogen peroxide-induced injury in HUVECs via the regulation of REDD1 and mTOR activation. Mol Med Rep 8: 147-153, 2013.
21. Zhu Y, Shi YP, Wu D, Ji YJ, Wang X, Chen HL, Wu SS, Huang DJ and Jiang W: Salidroside protects against hydrogen peroxide-induced injury in cardiac $\mathrm{H} 9 \mathrm{c} 2$ cells via PI3K-Akt dependent pathway. Dna Cell Biol 30: 809-819, 2011.

22. Fujihara M, Nagai N, Sussan TE, Biswal S and Handa JT: Chronic cigarette smoke causes oxidative damage and apoptosis to retinal pigmented epithelial cells in mice. PLoS One 3: e3119, 2008.

23. Mao H, Seo SJ, Biswal MR, Li H, Conners M, Nandyala A, Jones K, Le YZ and Lewin AS: Mitochondrial oxidative stress in the retinal pigment epithelium leads to localized retinal degeneration. Invest Ophthalmol Vis Sci 55: 4613-4627, 2014.

24. Shi K, Wang X, Zhu J, Cao G, Zhang K and Su Z: Salidroside protects retinal endothelial cells against hydrogen peroxide-induced injury via modulating oxidative status and apoptosis. Biosci Biotechnol Biochem 79: 1406-1413, 2015.

25. Qiao Z, Xu YW and Yang J: Eupatilin inhibits the apoptosis in $\mathrm{H} 9 \mathrm{c} 2$ cardiomyocytes via the Akt/GSK-3 $\beta$ pathway following hypoxia/reoxygenation injury. Biomed Pharmacother 82 : 373-378, 2016.

26. Lv D, Bai Z, Yang L, Li X and Chen X: Lipid emulsion reverses bupivacaine-induced apoptosis of $\mathrm{h} 9 \mathrm{c} 2$ cardiomyocytes: PI3K/Akt/GSK-3 $\beta$ signaling pathway. Environ Toxicol Pharmacol 42: 85-91, 2016.

27. Ramírez-Sánchez J, Simões Pires EN, Nuñez-Figueredo Y, Pardo-Andreu GL, Fonseca-Fonseca LA, Ruiz-Reyes A, Ochoa-Rodríguez E, Verdecia-Reyes Y, Delgado-Hernández R, Souza DO and Salbego C: Neuroprotection by JM-20 against oxygen-glucose deprivation in rat hippocampal slices: Involvement of the Akt/GSK-3 $\beta$ pathway. Neurochem Int 90: 215-223, 2015.

28. Yang P, Peairs JJ, Tano R and Jaffe GJ: Oxidant-mediated Akt activation in human RPE cells. Invest Ophthalmol Vis Sci 47: 4598-4606, 2006.

29. Yan T, Bi H and Wang Y: Wogonin modulates hydroperoxide-induced apoptosis via PI3K/Akt pathway in retinal pigment epithelium cells. Diagn Pathol 9: 154, 2014

30. Wang K, Jiang Y, Wang W, Ma J and Chen M: Escin activates AKT-Nrf2 signaling to protect retinal pigment epithelium cells from oxidative stress. Biochem Bioph Res Commun 468: $541-547,2015$. 